\title{
PEOPLES, STATES AND ISLAMIC INSURGENCY IN AFRICA
}

HerberT EKWE-EKWE

Africa: What a season... Beginning in early January 2015, the Boko Haram islamist insurgents in north Nigeria murder 2000 children, women and men, exponentially expanding the ruthlessness and savagery that have been the dual hallmark of this organisation... In a season when al-Shabaab of Somalia in Kenya expands its near-decade-old killing fields... In a season when hundreds of other Africans who wish to emigrate to Europe drown in the Mediterranean... In a season when a number of non-South African Africans are being murdered in South Africa by their hosts... In a season when scores of Africans are murdered in Burundi by the head of incumbent regime forces and generals and their subalterns engaged in yet another dreadful firefight to seize state power somewhere in Africa...

As the world witnessed in those early days of January 2015, rarely have there been two dreadful massacres of peoples carried out almost simultaneously in two separate continents by two organisations surely operating autonomously but belonging to the same overarching religious political agency. As we have already noted, Boko Haram, the islamist insurgent group based in north Nigeria, massacred 2000 people in Baga (The Guardian, London, 10 January 2015) during the course of two days. In Paris, France, over a 2-day stretch, during the same week, a French-based cell affiliated to some islamist caliphate brigade in the Mid East massacred 17 people including cartoonists of the satirical journal, Charlie Hebdo, and staff and shoppers at a Jewish supermarket.

Boko Haram is ideologically allied to the global islamist causes and projects of the Mid East amalgam including al-Qaeda in the Arabian peninsula and the Islamic State (controls vast swathes of territory in Iraq and Syria), as well as the Taleban in Afghanistan and al-Qaeda in the Islamic Maghreb in west/northwest Africa 
and al-Shabaab in Somalia. Boko Haram leader Abubakar Shekau never tires to extend solidarity messages to these fellow organisations in his regular video releases that update the strategic objectives and expectations of the ongoing transnational insurgency. Boko Haram has since formally aligned itself to the Islamic State, calling itself the Arabic equivalent of the caliphate of West Africa.

The responses of Nigeria and France to these tragedies couldn't be so trenchantly different though. Right from the outset, the French state robustly came out in defence of its population. It mobilised the entire range of its security forces to hunt down the murderous cell, stepped up security for its citizens whilst continually reassuring them, attended to the dead, the dying and the wounded, and organised a solidarity march in honour of the 17 and their families and for the reaffirmation of the crucial tenets and ethos that underpin the existence of the French republic. 3.5 million French people turned out in Paris on Sunday 11 th January for this historic gathering. The heads of state or government of most countries of the European World and beyond attended the march in support of France. The global media covered this story of a week comprehensively.

\section{MORBID SILENCE}

In Nigeria, in contrast, the country's regime-leadership and its expanded establishment exercised a morbid silence over the outrage in Baga - not a word on Baga from the head-of-regime nor from any of the seven ex-heads of regime. None of the eight was moved to act in defence of Baga from its notorious assailants, not even in the wake of that haunting, graphic account of the tragedy of his town rendered soon after by Baga district head survivor Baba Abba Hassan: “... most victims are children, women and elderly people who could not run fast enough when insurgents drove in ... firing rocket-propelled grenades and assault rifles on town residents" (The Guardian, London, 10 January 2015). Silence, punishing silence, utter silence... Such was the staggering indifference displayed by the Nigeria state to this massacre, within its 
frontier, that an observer would be forgiven if they thought that the slaughter that occurred in Baga never happened or that Baga were somewhere else on the planet or, perhaps, that Baga didn't really exist... In effect, this state no longer pretends that it exists to serve its peoples (for an expansive discourse on this feature, see Herbert Ekwe-Ekwe, Readings from Reading: Essays on African Politics, Genocide, Literature, 2011). If anyone is still unsure of this crucial characteristic, a reminder of the final segment of Nigeria's response to these massacres of a week might be of help: despite the silence on Baga, the state's head of regime found the time and purpose to send a message of condolence to the French head of state on the murder in Paris; equally silent on Baga, another senior regime official found the time and purpose to tweet a message of condolence to the people of France on the murder in Paris. It shouldn't be found surprising to add that no one marched in Nigeria on behalf of the 2000 murdered in Baga nor for their families nor indeed for any exhortative values of a doubtful state. As for the world's media, the lenses of their camera, during the week, were of course focused 2600 miles away from Baga - Paris.

It is to this focus of the world media and some of its wider consequences that led Simon Allison of the Daily Maverick to observe: "It may be the 21st century, but African lives are still deemed less newsworthy - and, by implication, less valuable - than western lives" (The Guardian, London, 12 January 2015). Allison is undoubtedly alluding to the catastrophic diminution of the African humanity by the pan-European World (especially Britain, France, Portugal, Belgium, Spain) during 400 years of the latter's enslavement of African peoples and its conquest and occupation of Africa. But as we now show, the perceived "less valuable" status of African life in the contemporary epoch has not just been a teleological transposition from a somewhat distant past. On the contrary, it is a thoroughly, consciously mapped-out package and practice designed and formally launched much more recently, in the mid-1960s, by a not-too-unfamiliar global power central in this visceral African subjugated history/international politics. 


\section{DIARCHY}

Let us again return to Nigeria's deafening silence on Baga. Given Nigeria's past and recurring history, does one realistically expect this state to defend Baga from Boko Haram, comment or mourn the murder of the 2000 from Baga - almost 49 years to the day after it embarked on the murder of 3.1 million of its Igbo population in a studiously-organised genocide that is still ongoing? Each of the seven of Nigeria's ex-heads of regime, referred to earlier, is a structural participant in this foundational genocide of post-(European)conquest Africa. They all constitute a génocidaire septet. This genocide at once shapes the architecture of the present Nigeria establishment, as the world knows it. Therefore, no one from any spheres or realm of this state assemblage could have had anything intelligible or/and credible to say on Baga. Part of the reason of Nigeria's silence on Baga is that given the country's genocide antecedent, few would have believed any word declared on this massacre by any officials of its state.

Britain, the ex-conqueror/occupying state in Nigeria supported the Igbo genocide from conceptualisation to execution. In supporting the genocide, Britain sought to "punish" the Igbo for being in the vanguard, since the 1930s, to terminate the British occupation of Nigeria - one of the very prized lands of the British conquest of Africa. During the course of the 1968/1969 gruesomely devastating apogee of the genocide, Harold Wilson, the British prime minister, informed C. Clyde Ferguson, the US state department special coordinator for relief to Biafra, that he, Harold Wilson, "would accept a half million dead Biafrans if that was what it took" Nigeria to destroy the Igbo resistance to the genocide (Roger Morris, Uncertain Greatness: Henry Kissinger and American Foreign Policy, 1977: 122). For the record, Wilson's "a half a million dead Biafrans"-wish represented 4.2 per cent of the Igbo population then; by the time that that phase of the genocide came to an end, 6-9 months after Wilson's wish-declaration, 25 per cent of this nation's population or 3.1 million Igbo people had been murdered by the genocidists.

Undoubtedly, the Nigerians had handsomely obliged Harold Wilson's wish. Those punching words of historian Chancellor 
Williams's were at once vindicated, most dramatically: “... The Europeans had also been busily building up and training strong African armies. Africans trained to hate, kill and conquer Africans..." (Chancellor Williams, The Destruction of Black Civilization, 1987: 218). In the construction of the template of international relations that would embody the post-World War II era, the British-Nigerian genocide diarchy had elevated the "dispensability of African life in national and international politics" to the highest calibrated level possible.

\section{WHOSE STATE?}

Inevitably, the question uppermost in the mind of every serious scholar on this subject is: The state in Africa - Whose state is it? In a background paper Ifeanyi Menkiti, the renowned philosopher and academic at Wellesley College, circulated last year January (2014) on the theme of the focus for a conference at Wellesley College on "John Rawls and Africa", from where the quote above is derived, he refers to that much popularly expressed assertion by Kwame Nkrumah, the philosopher and Ghanaian statesperson, "Seek ye first the political kingdom and all other things shall be added unto you", and notes that "Nkrumah, in hindsight, appears to [be] more right than he imagined though not for the reasons he imagined". I couldn't agree more with Professor Menkiti and it is on this "though not for the reasons [that Kwame Nkrumah] imagined" that I wish to reflect on in this paper.

In its annual "The failed States Index" surveys by the Washingtonbased Fund for Peace research institute, African countries, unsurprisingly, fare most poorly at each and across the 12 crucial variables at the centre of the fund's research, but particularly in the following six, with the inescapable crushing consequences on the lives and wellbeing of the peoples:
1. legitimacy of the state
2. rise of fractionalised elite
3. chronic and sustained human rights violation
4. uneven economic development
5. poorly, sharp and severe economic decline
6. massive movement of refugees or internally displaced persons. 
Thus, the highlights for Africa for one of the fund's recent research make for depressing reading and are as follows: 16 out of the world's "worst 20 states"; 20 out of the "worst 30 states"; 34 (well over one-half of all the continent's so-called sovereign states) of the "worst 54 states" (Fund for Peace, "The Failed States Index 2013". It is not inconceivable, given this rate of state failure, that, in the next five years, by the time the beginning of the next decade, 2020, "54 out of the worst 54 states" in the world could be in Africa!

For the purposes of this paper, the following two key empirical determinants of state failure are indeed paramount: (1) the state's inability to provide security and (2) the state's inability to provide essential social services. Let us elaborate on each of them:

1. The state's inability to provide security to its population This situation may have arisen because the state no longer exercises control across part/parts or all of its territory. Factors such as catastrophic breakdowns in vital internal sociopolitical and economic relations, intra-regime fractionalism and rivalries, external invasion and occupation of territory, and unmanageable natural disasters would contribute to the failure. It could also be due to the state's violation of the human rights of the people(s) including a deliberate state policy to embark on the destruction of one or more of its constituent nations/peoples/religious groups, etc., etc.

2. The state's inability to provide essential social services (communication infrastructure, health care, education, housing and recreation, development of culture) to its people(s) or the state's deliberate policy to deny or partially offer such services to some of its constituent nations/peoples/religious groups... This failure could be the consequence of a state's dwindling fiscal/ material resources or just sheer incompetence in its management capacity. Alternatively, this inability points to the staggering nature of corruption and largely institutionalised norm of non-accountability in the access and control of public-owned finances by state officials and their agents.

Christopher Clapham has argued that the concept "failed-state" is "one of those categories that is named after what it isn't, rather than what it is" (Christopher Clapham, "Failed States and 
Non-states in the Modern International Order", paper presented at conference on failed states, Florence, Italy, April 2000. This is vital in the discourse to the effect that a state, such as Nigeria or Sudan or Rwanda for instance, that embarks on the genocide of its population or does not provide basic services for its people or immanently churns out successive regimes that fleece the collective wealth of the country can hardly merit such a definition in social science. All we need do to highlight the obvious flaw in applying this concept in Africa is to reflect on the fact that crucial state functions such as the provision of security, rule of law, a rationalising but flexible structure of management, accountability and open and unfettered competition, especially with respect to "regime change", have not been in operation in any African state since the conquest and occupation of most of the continent by a constellation of European countries in the 19th century. Tragically, in the 59 years since the concerted African drive towards the restoration of its independence resulted in the supposedly 1956 breakthrough in the Sudan, followed soon in 1957 by Ghana, the situation has not changed significantly in Africa for the realisation of these attributes of the state.

Ultimately, the major limitation of the use of the "failed-state" concept to assess the catastrophic situation in contemporary Africa is that it confers an unjustifiable presumption of rationality to an enterprise in which a spectrum of outcomes ranging from perhaps "failure" to "outright failure" to "disaster" is predetermined; it is assumed that those who run the state in Africa (Obasanjo, Idi Amin, Taylor, Moi, Habre, Doe, Gowon, Mobutu, Ahidjo, Jonathan, Rawlings, Obote, Babangida, Mengistu, Abacha, Mugabe, dos Santos, Mohammed, Banda, Abubakar, Bokassa, Jammeh, Eyadema, Buhari, Toure, Museveni, Yar'Adua, Biya, Al-Bashier ...) are aware of this test and its evaluative scruples and, like any rational participant, would want to succeed... If they do not do so well, at some instance, so goes the logic, they will try to improve on their previous score and, hopefully, do better... Success is always a possibility! It is on the basis of this possibility that Roland Oliver concludes his own controversial contribution to this debate. If one, for a moment, ignores the gratuitous racism and paternalism embedded in the 
premise of Oliver's contribution as well as the highly contestable analytical category on which it is hinged, which I will be focussing on shortly, Oliver notes: "With its overriding population problem, Africa can hardly expect to achieve First World standards of economic development within the next century [i.e. 21st century] but with just a little more day-to-day accountability, it could at least recover the confidence to continue the uphill struggle with more success" (Roland Oliver, "The condition of Africa", Times Literary Supplement, London, 20 September 1991: 9). On the contrary, there is limited indication on the ground that African state operatives currently or indeed in the past 59 years have approached statecraft as a challenge to succeed in transforming the lives of their peoples. "Success" is never a goal set along the trajectory of their mission. To that extent, Oliver's conclusion is, ironically, quite optimistic. Furthermore, it should be noted that given the evidently limited concerns on just "measuring" the scoreboard of performance, "failed-states" discourses tend to overlook the much more expansive turbulence of underlying history - the kind of project that is being mounted here in this presentation.

\section{DOUBLE JEOPARDY}

In the past year, there have been heartened commemorations in Britain and elsewhere in Europe of a century of the beginning of the 1914-1918 war or First World War or the Great War. Noticeably, a recurring theme in the media (and academia) that has been used to articulate African role in this war is "hidden" or "silent", even "unknown". There was indeed an academic who appeared in one of the British Broadcasting Corporation's frontline current affairs newsmagazine programmes who used the bizarre phrase "not really well known" in describing "African involvement". "Hidden", "silent", "unknown", "not really well known" - by whom?!

All of Africa lost one million of its peoples fighting in this war caused and waged principally by the leading European conqueror-states of the era in battle fronts in East Africa, Cameroon (west Africa) and in Europe itself. In this incalculable tragedy, these Africans, conscripted by their varying European-occupying powers 
in Africa (Britain, France, Belgium) fought for Britain, France, Belgian, Czarist Russia, and their allies against Germany, Italy, Austro-Hungary, the Ottomans, and the latter's allies; on the opposing side of this frontline, other occupied Africans (conscripted by Germany and Italy) fought for Germany, Italy, Austro-Hungary, the Ottomans, and their allies against Britain, France, Belgian, Czarist Russia and their allies.

Essentially, this was a war, in addition to the follow-up 19391945 confrontation, that Africa and Africans had no business, whatsoever, fighting in. The two principal protagonists in each conflict, Britain and Germany, were lead powers in the pan-European World conqueror-states that had formally occupied Africa since 1885. Britain was indeed the foremost conqueror of Africa from the group, having occupied the continent's prized lands lands with major population centres and vast and multiple natural resource emplacements in south, central, east and west regions: South Africa, Namibia (proxy control, post-1918 - after the defeat of Germany in 1914-1918 war), Zimbabwe, Botswana, Swaziland, Lesotho, Zambia, Kenya, Uganda, Tanzania (post-1918, after the defeat of Germany in 1914-1918 war), the Sudan, Nigeria, south Cameroon (post-1918, after the defeat of Germany in 1914-1918 war), Ghana, Sierra Leone, Gambia. Britain is also the lead beneficiary of this same pan-European World states' 400 years of enslavement of African peoples, mostly in the Americas, since the 15th century Contemporary Era (CE) (Herbert Ekwe-Ekwe, Readings from Reading: Essays on African Politics, Genocide, Literature, 2011, especially chap. 1).

As for Germany, beginning in 1904 and ending in 1911, i.e., prior to the 1914-1918 war, it had carried out the genocide of the Herero, Nama and Berg Damara peoples in its occupied Namibia in southwest Africa with the following catastrophic outcome during the period: wiped out 80 per cent of Herero, 51 per cent of Nama, 30 per cent of Berg Damara (Herbert Ekwe-Ekwe, African Literature in Defence of History, 2001: 37-38). For Belgium, an Anglo-French ally in the 1914-1918 war, indeed the state whose initial attack by Germany triggered this conflict, it, too, entered the intra-European war in 1914 in the wake of committing a 30-year trail 
(1878-1908) of genocide against Africans in the Congo basin in central Africa which it annihilated 13 million constituent peoples (see, especially, multiple research by historian and linguist Isidore Ndaywel è Nziem, Histoire générale du Congo: De l'héritage ancien à la République Démocratique [Paris: Duculot, 1998], p. 344).

Of course, nothing about the role of Africa and Africans in this conflict is "hidden" or "unknown". On the contrary. What has duly been the difficulty that the presumed "gatekeepers" of this history (who have all along been tireless "rationalisers" of the European conquest and occupation of Africa) have had is how to explain the very perverse role of desperately occupied peoples fighting a war of/for their occupiers. I have argued in a number of studies (see, for instance, African Literature in Defence of History, chap. 1 and EkweEkwe, Africa 2001: The State, Human Rights and the People, 1993, especially parts I-II) that two critical developments of the 20th century - the wars of 1914-1918 and 1939-1945 - shatter the cardinal features of the position of these "rationalisers" irrevocably:

(a) The 1919 treaty of Versailles that ends the 1914-1918 war frees all subjugated European peoples in Russia, Austro-Hungary and the Ottoman whilst African peoples in German-occupied Africa (Namibia, Tanzania, Cameroon, Togo, Rwanda, Burundi) do not have the restoration of their freedom but are, instead, occupied by Britain, France and Belgium (ironically, latter two countries hardly withstood the 1914 German juggernaut)!

(b) Africans in mostly British-occupied, French-occupied and Belgian-occupied Africa are again conscripted, beginning in the autumn of 1939, to fight against Germany, as the new war erupts, even though Germany had, since 1918, ceased to be a conqueror/ occupying-state in Africa

(c) Africans in mostly British-occupied and French-occupied Africa are conscripted, beginning in the autumn of 1939, to fight against Japan, in the forests of Myanmar, even though the Japanese were not and have never been conquerors or occupiers of Africa

(d) Belgian king and state which barely resisted the German assault on their territory beyond three weeks in May 1940 had the entire financing of the Belgian war effort (including the entire 
expenses of the country's exiled royal family and government in London), totalling $£ 40$ million, paid for by Belgian-occupied Congo; this is the same Belgian-occupied Congo where the Belgian monarch and state had murdered 13 million Africans in the 30-year old genocide cited earlier

(e) Thousands of Africans perish in the battle fronts of east Africa, Europe and south Asia fighting for Anglo-Franco-Belgian conquerors/occupiers of Africa

(f) Restoration of African independence in the post-war epoch is distinctly rejected by British Prime Minister Winston Churchill in a November 1942 speech in London ("I have not become the King's First Minister in order to preside over the liquidation of the British Empire", he stresses, "From the archive: Mr Churchill on our one aim", The Guardian, London, 11 November 2009) in his own interpretation of the August 1941 "Atlantic Charter", formulated by him and US President Franklin Roosevelt, which declares unambiguously: "all people had a right to self-determination"

(g) In similar vein, Charles de Gaulle, leader of the "Free French Forces" who had been on exile in England since Germany overran France in 1940, rejects African independence in the post-war era during a 1944 conference of global French occupation-governors in Brazzaville, Congo

(h) Writing in The Mail on Sunday (London, 23 August 2014), George Carey, a former archbishop of Canterbury, recalls: "This year we are reminded by the commemoration of two world wars that the values of our democratic traditions are precious. Our fathers and grandfathers ...fought against totalitarianism for the survival of democratic virtues". Pointedly, Carey's hearty summation does not incorporate the African experience as we have highlighted here. Such has been the asymmetrical character of this history that besides Japan, Czarist Russia/Soviet Union and Austro-Hungary, Africa has been largely under an unparalleled totalitarian straitjacket enforced, since 1885, by each and every dominant state across those two strategic battle lines that map the 1914-1918 and 1939-1945 wars. 
Following from (f) and (g) [above], it is in fact no coincidence that Britain would wage two devastating wars against two African nations at the forefront of terminating its occupation of Africa in the immediate post-1939-1945 war era: against the Gĩkũyũ in the east in the 1950s, with the death of tens of thousands of Gĩkũyũ and others and in co-perpetrating the Igbo genocide in west Africa with the state in Nigeria, 1966-1970, with the murder of 3.1 million Igbo or one-quarter of this nation's population. Both the Gĩkũyũ and Igbo had spearheaded the liberation of Kenya and Nigeria respectively from the British occupation.

It should now be evident that on a broader stretch of examination, there can't be any such thing as "hidden" history. Instead, what some practitioners wish to do is obfuscate or, worse, deny. Writing on the "Concept of History", Walter Benjamin has argued that the "past carries a secret index with it, by which it is referred to its resurrection", accessed 19 May 2015). He poses two pressing questions: "Are we not touched by the same breath of air which was among that which came before? [I]s there not an echo of those who have been silenced in the voices to which we lend our ears today?" He is uncompromisingly forthright in response:

...The Angel of History must look just so. [Its] face is turned towards the past. Where we see the appearance of a chain of events, $[i t]$ sees one single catastrophe, which unceasingly piles rubble on top of rubble and hurls it before [its] feet ... nothing which has ever happened is to be given as lost to history. Indeed, the past would fully befall only a resurrected humanity. Said another way: only for a resurrected humanity would its past, in each of its moments, be citable. Each of its lived moments becomes a citation a l'ordre du jour [order of the day] - whose day is precisely that of the Last Judgement.

At the crux of trying to manufacture this phantom of "lost to history", as far as Africa and Africans are concerned, Chinua Achebe's invaluable insight follows and we will quote him at length:

[The European conquest of Africa] may indeed be a complex affair, but one thing is certain: You do not walk in, seize the land, the person, the history of another, and then sit back and compose hymns of praise in his honour. To do that would amount to calling yourself a bandit; and you won't to do that. 
So what do you do? You construct very elaborate excuses for your action. You say, for instance, that the man in question is worthless and quite unfit to manage himself or his affairs. If there are valuable things like gold and diamonds which you are carting away from his territory, you proceed to prove that he doesn't own them in the right sense of the word - that he and they had just happened to be lying around the same place when you arrived. Finally if the worse comes to the worse, you may even be prepared to question whether such as he can be, like you, fully human. From denying the presence of a man standing there before you, you end up questioning his very humanity ... [I]n the [European conquest] situation presence was the critical question, the crucial word. Its denial was the keynote of [this conquest's] ideology. (Chinua Achebe, "African Literature as Restoration of Celebration", Kunapipi, 12, 2, 1990: 4; emphasis added.)

So, rather than relations that bring benefits to many of its people, the state in Africa has "evidently been a source of suffering", to quote Clapham ("Failed States and Non-states in the Modern International Order"), an imagery consistent with Basil Davidson's description of the impact of this state on the African humanity as a "curse" (Basil Davidson, Black Man's Burden: Africa and the Curse of the Nation-State [London: James Currey, 1992]). Richard Dowden also uses a health metaphor to capture the legacy of the African state when he notes, alluding to its genesis: "[this European]-scissors and paste job [has indeed caused Africa] much blood and tears" (Richard Dowden, "Redrawing the outmoded colonial map of Africa", Independent [London), 10 September 1987]). For her own observation, Lynn Innes is in no doubt that the state in Africa has created what she describes as a "deeply diseased [outcome]" on the continent (C.L. Innes, Chinua Achebe [Cambridge: Cambridge University, 1990: 151]). The health metaphor stretches even to the psychiatric as Thomas Pakenham observes: "One has only to think of the bloody ... wars that followed decolonisation to see the craziness of these lines drawn on maps in Europe by men ignorant of African geography and history" (Thomas Pakenham, "The European share-out of the spoils of Africa", Financial Times [London], 15 February 1988). Chester Crocker points to the fundamental problem of the state in Africa. It is "not the absence of nations; it is the absence of states with 
the legitimacy and authority to manage their affairs ... As such, they have always derived a major, if not dominant, share of their legitimacy from the international system rather than from domestic society" (Chester Crocker, "Engaging Failing States", Foreign Affairs, September/October 2003: 37). It is this question of alienability that is at the crux of this grave crisis.

As most people now know, the states that Europe created in Africa, in the aftermath of its November 1884-February 1885 Berlin conqueror-conference, cannot provide the fundamental needs of Africans. This "Berlin-state", whatever its "cursed" name, cannot lead Africans to the reconstructive changes they deeply yearn for after the tragic history of centuries of occupation. Indeed, such changes for African interests were never nor presently the intended goals for this state. On the contrary, this state, in its current character, is an instrument to continue to exploit African human and natural resources for the European World and its allies. Essentially, the "Berlin-state" still serves the interests of its creators and those of the cabal of African-overseers which polices the dire straits of existence that is the lot of Africans currently. In this context, the Boko Haram insurgency and those of other islamist groups in Africa are just part of the increasing pressure on the "Berlin state" or the post-(European)conquest state of Africa. Few now believe that the "Berlin state" is sustainable. Its "essence" remains, 130 years after its emergence, in the wake of conquest. This is precisely why it is presently unraveling as more and more constituent peoples or nations wish to proclaim their independence from a state they find inchoate, inorganic and alienating. Surely, the world will have to contend with an ever changing map of Africa based on the outcome of complex and profound internally-originating independence movements. It should therefore be made very clear that the majority of this is not islamic, despite the high drama of contemporary politics!

As European-conqueror powers demonstrated in Berlin back in 1884-85, the state is not a gift from the gods. On the contrary, the state is a relationship painstakingly formulated and constructed by groups of human beings on planet earth to pursue interests and aspirations envisioned by these same human beings within 
a shared historical and geographical articulation. The African humanity is presently gripped in a grave crisis for survival. It is now time that it abandoned the contrived "Berlin-state" in order to survive. This state is a bane of African existence. African nations, namely the Igbo, Ijo, Wolof, Ibibio, Asante, Baganda, Bakongo, Gĩkũyũ, Bambara, Luo, etc., etc, remain the basis for the regeneration of Africa's redevelopment. These nations are the sites of the continent's intellectual and other cultural creativity.

\section{PATH TO CIVILISATION - EVEN 1001 STATES IF NEED BE}

What is being stressed here is that African peoples, themselves, must decide on the issue of sovereignty in the post-"Berlin-state" epoch even if the outcome were to lead to the creation of 1001 states in Africa - or more. In this epoch of freedom, any African peoples who, for instance, wishes to chart a future based on the precepts of their forebears in the 12th century Contemporary Era (CE) or even way back, to say, 8th century Before Contemporary Era (BCE), as some movements would wish to proffer, has the right to pursue this goal. Equally any African peoples who believes that their aspirations lie in working through challenges of the $21 \mathrm{st}$ century $\mathrm{CE}$ and projecting targets of creativity and transformations subsequently must exercise this right. The right to self-determination is for every people. It is inalienable and is guaranteed by the United Nations. No people, any peoples, is exempt from exercising this right. This is why the slogan that proclaims such gibberish or ahistoricism as "indivisibility" / indissolubility" / indestructibili ty" of a state, any state, as expressed sometimes in some African circles, for example, is not really worth the paper it is written on except of course it is an embedded code by a slaughtering-horde for the plot of the next pogrom or the reinforcement of the terror of an ongoing genocide...

To achieve the goal(s) of any of the stipulated paths does not therefore require anyone to embark on murdering someone else or have themselves murdered, as typified, for instance, in a Nigeria, Kenya, Somalia, the Sudan, Central African Republic, wherever. For the future survival of the African humanity, let no more die for 
the path to their envisaged civilisation or, in other words, howsoever this civilisation a people chooses is construed. It surely can be attained and sustained without committing a crime, particularly genocide - a crime against humanity. 